\title{
First record of a basal neoceratopsian dinosaur from the Late Cretaceous of Kazakhstan
}

\author{
Alexander Averianov and Hans-Dieter Sues \\ Acta Palaeontologica Polonica 54 (3), 2009: 553-556 doi: http://dx.doi.org/10.4202/app.2008.0079
}

The oldest known ceratopsians come from the Late Jurassic of China (Zhao et al. 1999; Xu et al. 2006). During the Early Cretaceous, the basal ceratopsian Psittacosaurus was among the most common dinosaurs in Asia but more derived basal neoceratopsians were quite rare on that continent (Xu et al. 2002; Makovicky and Norell 2006). Basal neoceratopsians became more abundant in the Late Cretaceous of Mongolia and China, although they are not known in this region from the latest Cretaceous (You and Dodson 2004; Alifanov 2008). In contrast, basal neoceratopsians are rare during the Early Cretaceous in North America but became common and diverse during the Campanian and Maastrichtian (You and Dodson 2004; Chinnery and Horner 2007). Little is known about the evolutionary history of this group in more inland regions of what are now Kazakhstan and adjoining countries. Asiaceratops documents the presence of basal neoceratopsians in the Cenomanian of Uzbekistan (Nessov et al. 1989). Here we report on the first record of a basal neoceratopsian in the Late Cretaceous of Kazakhstan, based on two cranial bones from the Turonian Zhirkindek Formation in the northeastern Aral Sea region.

Alexander Averianov [lepus@ zin.ru], \{provide institution name in Russian, transliterated

Zoological Institute, Russian Academy of Sciences, Universitetskaya nab. 1, Saint

Petersburg 199034, Russia; Hans-Dieter Sues [suesh@si.edu], National Museum of Natural History, Smithsonian Institution, MRC 106, P.O. Box 37012, Washington, DC 20013-7012, U.S.A.

This is an open-access article distributed under the terms of the Creative Commons Attribution License (for details please see creativecommons.org), which permits unrestricted use, distribution, and reproduction in any medium, provided the original author and source are credited. 
FoF Full text $(248.1 \mathrm{kB})$ 